\title{
Psychological Knowledge Relevant to Leadership in Wildlife Conservation
}

\author{
Simon A. Black \\ Durrell Institute for Conservation and Ecology, University of Kent, Canterbury, UK \\ Email: s.black@kent.ac.uk
}

How to cite this paper: Black, S. A. (2019). Psychological Knowledge Relevant to Leadership in Wildlife Conservation. Open Journal of Leadership, 8, 114-141. https://doi.org/10.4236/ojl.2019.83007

Received: July 19, 2019

Accepted: September 20, 2019

Published: September 23, 2019

Copyright $\odot 2019$ by author(s) and Scientific Research Publishing Inc. This work is licensed under the Creative Commons Attribution International License (CC BY 4.0).

http://creativecommons.org/licenses/by/4.0/

\begin{abstract}
This study aims to identify whether a published leadership framework recommended for conservation professionals aligns with knowledge established in the wealth of literature relating to the New Psychology of Leadership. Wildlife conservation involves the protection and recovery of endangered species, landscape protection or ecosystem reconstruction and is a sector in which leaders face complex systems of resource constraints, socio-political resistance and technical challenges. The literature on conservation leadership has grown in recent years but is rarely linked to an understanding of psychology. Studies have shown difficulties arising when a traditional power-based leadership approach is applied to conservation. Current psychological literature addressing leadership offers suitable alternatives to the traditional approach. This review identifies practical psychological research relating to competences including budgeting, planning, experimentation, training, governance and performance measurement as well as more obvious personal competences of interpersonal skills, vision, empowerment, cultural sensitivity. The findings from this review demonstrate that the most comprehensive current framework for conservation leadership appears valid in the light of contemporary psychological knowledge and is a robust guide which matches the context, constraints and challenges faced by leaders of wildlife conservation.
\end{abstract}

\section{Keywords}

Conservation, Psychology, Systems Theory, Competence, Followership

\section{Introduction}

Wildlife conservation involves recoveries of endangered species, landscape protection and ecosystem reconstruction under significant human pressures (e.g. 
pollution, land-use changes, urbanisation, population growth, hunting, wildlife trade). Conservation organisations typically suffer constraints including inadequate finances, a transient workforce and remote locations. Work can be physically demanding, slowed by bureaucracy, political interference, or local resistance (Clark et al., 1994; Kleiman et al., 2000; Black \& Copsey, 2014). While not unique to the sector, these challenges set a particular context for leaders' influence on conservation outcomes.

The conservation sector has, nevertheless, been slow to examine how to better lead and manage its work (Englefield et al., 2019) and several observers note a lack of leadership capacity-building to meet current and future challenges (Clark, 2001; Scheffer, Westley, \& Brock, 2003; Dietz et al., 2004). It is only in the last decade that conservation research has seriously examined leadership (Manolis et al., 2009; Black, Groombridge, \& Jones, 2011; Black \& Copsey, 2014; Bruyere, 2015; Straka et al., 2018), and how leaders influence conservation success (Black, et al., 2011; Gutiérrez, Hilborn, \& Defeo, 2011; Haubold, 2012). Studies have largely utilised views of conservation professionals (Dietz et al., 2004; Manolis et al., 2009; Bruyere, 2015; Englefield et al., 2019) or reviews of conservation practices (Black et al., 2011; Black \& Copsey, 2014; Bianco, Koss, \& Zischka, 2016).

Until now, conservation leadership has not been reviewed in the light of current psychological knowledge. This review was prompted by several key texts within wider psychological literature, covering topics of social identity (Haslam \& Reicher, 2016), power and innovation (Norbom \& Lopez, 2016), executive function (Ramchandran, Colbert, Brown, Denburg, \& Tranel, 2016), prototypical leadership (Haslam, Reicher, \& Platow, 2010), transactional-transformational models (Bass, 1997), cross-cultural factors (House et al., 1999), influence (Fiedler, 1964), antecedents and consequences (Ajzen, 1991; Wofford, Goodwin, \& Premack, 1992), performance (Henman, 2016; Knies, Jacobsen, \& Tummers, 2016), decision-making (Vroom \& Yetton, 1973), brain function (Jacobs, 2009; Ramchandran et al., 2016), positive psychology (Martin, 2005), goal-setting (Locke \& Latham, 1990), competency (Shippmann et al., 2000), motivation (Ryan \& Deci, 2000), followership (Van Vugt, Hogan, \& Kaiser, 2008), purpose and values (Crandall \& Rasmussen, 1975). These set a context to explore functions of leadership and paradigms of effective behaviour within the context of work encountered by leaders in wildlife conservation.

Traditionally leadership is associated with power (French \& Raven, 1959) including legitimate power (through formal roles), reward (pay, recognition), coercive power (punishment), referent power (personal characteristics), and expertise (superior knowledge or skill). Hersey \& Goldsmith (1980) add connection power (links with influential people) and (Raven, 2008) adds information power (convincing others with logic). Norbom \& Lopez's (2016) provide support for expert, reward, coercive, legitimate and connection power, but not information power. They note that information-sharing may, however, raise a leader's 
standing with followers, which is important in conservation since scientific data is critical to work design, decision making and planning (Black et al., 2013).

Within conservation literature Evans et al. (2015) follow Grint's (2005) typology in discussing broader environmental leadership (climate change, biodiversity, natural resources) in highlighting generic factors of "person" (behaviours, characteristics), "position" (hierarchy, bureaucracy), "process" (what leaders do), "results" (resource use, sanctions, conflict resolution), and "purpose" (direction and motivations). Four more specific dimensions of leadership practice are raised by Bengston \& Fan (1999) in relation to landscape conservation: land stewardship, ethics, collaboration, and scientifically informed decision-making. Even more specifically, Mattson et al. (2011) focused on leadership in a complex conservation programme (involving directors, funders, and policy makers), namely the large American "Yellowstone to the Yukon" multi-agency project. This highlighted the importance of vision, learning, power (including money), problem solving, and community engagement. Their study also identified a confounding "neo-corporatist" approach in organisations, causing rigid, homogenized thought and action which impedes learning, adaptation and effectiveness. Sutton (2015) evaluated a different type of conservation intervention, which involves the reintroduction of animal species into the wild, and identified four elements: an expert leadership team who "champion" the project, hierarchies which also allow individual autonomy, goals and progress checks, and culturally relevant public outreach. In carnivore projects, similar concepts apply: gaining trust among affected people, representing stakeholders, valuing knowledge (experience, tradition, or science), collectively agreeing goals, and empowerment (Sjölander-Lindqvist, Johansson, \& Sandström, 2015). These aspects resonate with earlier general studies of conservation effectiveness (Black et al., 2011; Black et al., 2013; Black \& Copsey, 2014) and more recent syntheses (Knight et al., 2019; Mahajan et al., 2019) which suggest a move away from traditional models of leadership and management.

Those needs in conservation resonate with the "new psychology of leadership" (Haslam \& Reicher, 2016) which moves power out of the leadership construct and describes leadership as "an influence process that centers on group members being motivated to reach collective goals ... ultimately proved by followership". Leadership is less about the traditional focus on "I" (the leader) to be about "we" internalised by team members as "shared group membership that leaders create, represent, advance, and embed" (Haslam \& Reicher, 2016). This "new psychology of leadership", is a process, namely what leaders do, in influencing people's willingness to follow (Haslam \& Reicher, 2016). Trust becomes important, particularly where people or outcomes are interdependent or risky (Rousseau, Sitkin, Burt, \& Camerer, 1998; Clegg et al., 2002).

These contemporary developments in general leadership research resonate with the needs of conservation leaders who commonly have to delegate technically risky tasks or have colleagues working in remote locations (or both) along- 
side socio-political and resource challenges (Black \& Copsey, 2014). Interestingly there is already evidence in conservation literature which indicates that when leaders rely on traditional power (e.g. reward, hierarchy, reputation, bureaucracy) they lose effectiveness (Clark et al., 1994; Turvey, 2009; Quammen, 2012) since controls become a de facto purpose and shift people's focus and priorities away from the conservation of species.

There is a recognition that new skills are needed by leaders in conservation (Knight et al., 2019). Clark (2001) suggests the sector has been guilty of training "idiot savants", with technical expertise, but inept at human interaction, problem-solving, engaging with inter-disciplinary perspectives, critical thinking and influence. Cannon, Dietz, \& Dietz (1996) found that 78\% of sampled conservation employers considered people skills (e.g. group decision-making, interpersonal communication, leadership) equal or more important than scientific knowledge. A survey of conservation professionals identified the importance of similar skill areas (Bruyere, 2015), emphasising "vision building/values definition", "adaptive management", "conflict management and partnership building". Recently Englefield et al. (2019) identified that many important leadership skills are still rarely encountered in the behaviour and actions of conservation leaders, including vision, building trust and enabling others. These studies illustrate the breadth of topics relevant to this review which still need to be better understood in the context of modern psychological knowledge of leadership.

\section{Methodology for this Review}

There has been a rise in general leadership literature (Table 1, Web of Science searches A and B). Search C shows that psychology appears in conservation research. Previous reviews of conservation leadership using the Web of Science database, searched "(conservation biology OR conservation science) AND leadership" (Manolis et al., 2009; Bruyere, 2015) which when repeated reveals the continued growth in publications (Table 1, Search D). Search E, however, reveals that almost none of this material relates to the psychology of leadership in conservation. The broader search " $\mathrm{C}$ " (Table 1) covers relevant studies on decision-making, organisation assessment, governance, community participation, collaboration, values, behaviour, and planning (plus some irrelevant topics such as leading recycling and leadership in animals, as noted by Bruyere, 2015). The number of articles (Searches A-D) has risen annually since 2008 with "leadership AND psychology" at an average of 31 new articles per week in 2018. The literature available on other databases reflects the extent of material (Table 2) that needs to be filtered in this review.

Currently, the range of topics discussed in conservation leadership literature is fragmented from article to article, so to collate relevant leadership articles in this review a comprehensive reference framework was needed. Black et al.'s (2011) conservation leadership framework is considered by Case et al. (2015) as being the most comprehensive leadership model in conservation, covering 41 areas of 
capability including psychological aspects of follower trust, decision-making, openness, identity, goal-setting, attention (by the leader), sense of purpose (for teams and individuals) and motivation. Black et al.'s (2011) framework is also one of the most heavily cited (27 times against an average of 19.4 for all articles since 1970 on Search D, Table 1). It resonates with the new psychology of leadership (Haslam \& Reicher, 2016) and also draws on the theories of open systems, variation, and knowledge (Black \& Copsey 2014). The constructs in Black et al.'s (2011) framework form the boundary for this review of psychological and management research (including performance, groups, multi-culture, improvement, and bureaucracy) covering four areas of capability:

1) Vision and goals (purpose, knowledge, plans, governance, metrics);

2) Hands-on leadership (involvement, listening, cultural sense, delegation);

3) Consider details and big picture (problems, budgets, funding, partners);

4) Improvement and learning (capability, error management, training).

Table 1. Number of articles on Web of Science appearing against key search terms.

\begin{tabular}{|c|c|c|c|c|c|c|}
\hline \multirow[b]{2}{*}{ SEARCH } & \multirow[b]{2}{*}{ Search Terms: } & \multicolumn{5}{|c|}{ Web of Science 1970 to 31 December each year: } \\
\hline & & 2008 & 2015 & 2016 & 2017 & 2018 \\
\hline A & Leadership & 17,500 & 39,177 & 43,703 & 78,612 & 88,146 \\
\hline B & $\begin{array}{l}\text { Leadership } \\
\text { and Psychology }\end{array}$ & 313 & 812 & 920 & 1426 & 1620 \\
\hline $\mathrm{C}$ & $\begin{array}{c}\text { (conservation biology OR } \\
\text { conservation science) } \\
\text { AND (leadership } \\
\text { OR psychology) }\end{array}$ & 49 & 121 & 139 & 219 & 250 \\
\hline $\mathrm{D}$ & $\begin{array}{c}\text { (conservation biology OR } \\
\text { conservation science) } \\
\text { AND leadership }\end{array}$ & 29 & 61 & 67 & 104 & 121 \\
\hline $\mathrm{E}$ & $\begin{array}{c}\text { (conservation biology OR } \\
\text { conservation science) } \\
\text { AND leadership } \\
\text { AND psychology }\end{array}$ & 0 & 1 & 1 & 1 & 1 \\
\hline
\end{tabular}

Table 2. Leadership search for the number of articles listed on major databases.

\begin{tabular}{ccccc}
\hline $\begin{array}{c}\text { Database: } \\
\text { Search Terms }\end{array}$ & $\begin{array}{c}\text { Google } \\
\text { Scholar }\end{array}$ & $\begin{array}{c}\text { Taylor \& } \\
\text { Francis } \\
\text { On-line }\end{array}$ & $\begin{array}{c}\text { EBSCOHOST } \\
\text { Psych } \\
\text { ARTICLES } \\
\text { Psych INFO }\end{array}$ & $\begin{array}{c}\text { Web of } \\
\text { Science }\end{array}$ \\
\hline Leadership & $1,290,000$ & 568,913 & 39,577 & 43,703 \\
$\begin{array}{c}\text { Leadership } \\
\text { and Psychology }\end{array}$ & $1,110,000$ & 169,955 & 15,733 & 920 \\
$\begin{array}{c}\text { (conservation biology OR } \\
\text { conservation science) } \\
\text { AND leadership }\end{array}$ & 17,700 & 32,487 & 261 & 67 \\
\hline
\end{tabular}


From this framework, 25 additional search terms were added to search $\mathrm{C}$ (Table 1), returning the set of article counts in Figure 1. The colloquial terms "hands-on" and "big-picture" had a zero return in the general literature, whilst "cultural sensitivity" was split into two for a meaningful return. There were no differences with plurals (e.g. "budgets" v "budget"). Search counts excluded less relevant material (e.g. sport, clinical psychology, sociology, occupational health). Duplicate appearances of articles occur at a rate of 1.87 across Black et al.'s (2011) four areas (Vision \& Goals 1.78; Hands-on Leadership 1.99; Details \& Big Picture 2.02; Improvement \& Learning 1.99) and duplication is also low in each of the 27 separate search terms (mean $=2.12, \mathrm{SD}=0.39$ ), mostly in the range 1.5 2.21. Topics are spread evenly across the literature. Web of Science counts since 2007 provide the bulk of relevant literature for this review, which is discussed hereafter under the four areas of capability in Black et al.'s (2011) framework. The articles cited and concepts discussed hereafter relate to the number of items identified in the searches as indicated in Figure 1.

\section{Vision and Goals}

The first area of capability in Black et al.'s (2011) framework describes the expectations and focus which the leader demonstrates through "Vision and Goals". Black et al. (2011) identified the need for leader to establish a purposeful organisation, pursuing an inspiring long-term vision which engages colleagues and stakeholders alongside practical and relevant short-term goals in a frame

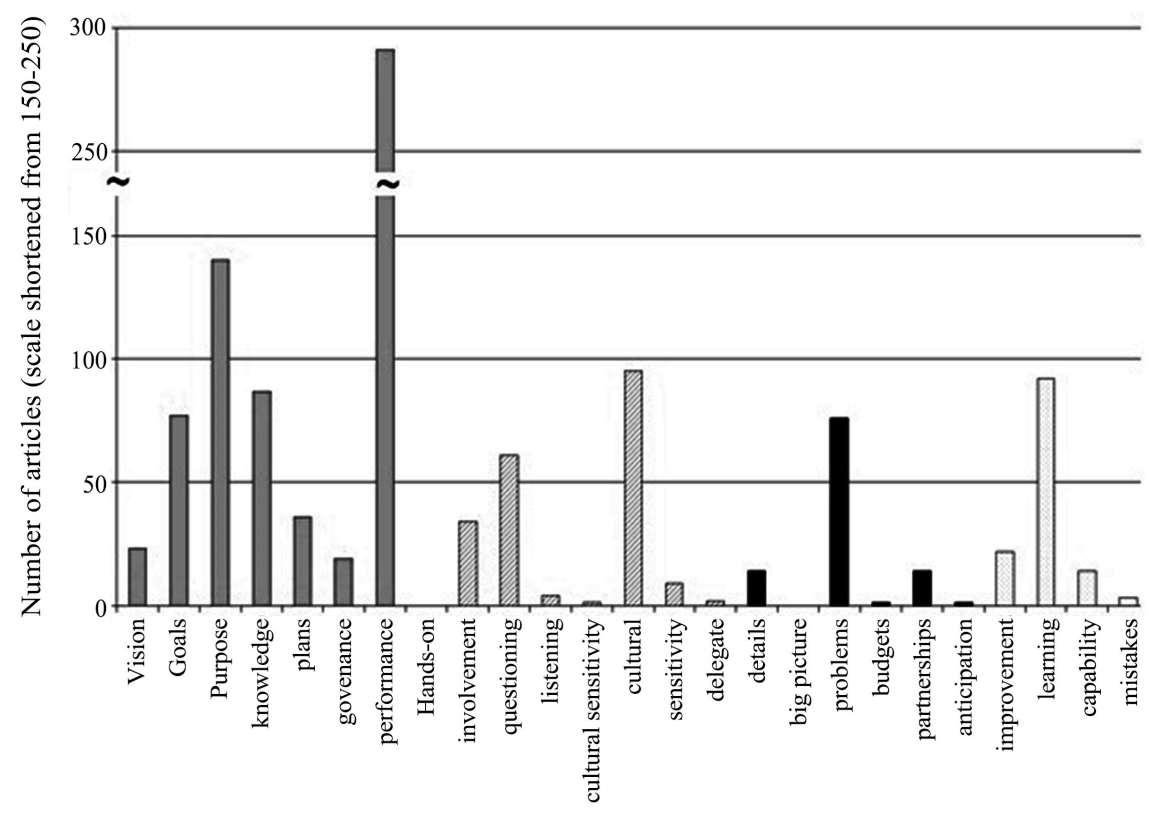

Search term additonal to Leadership AND Psychology

Figure 1. Articles on Web of Science (1970-2017) by search term. Bar colour indicates terms (l-r) collected into four leadership areas; vision \& goals (grey); hands-on leadership (hashed); details \& big picture (black); improvement \& learning (white). The Y-axis is shortened at $150-250$ articles. 
work of performance measures and accountability (governance). This relates to the following themes encountered in literature covering the psychology of leadership.

\subsection{Purpose, Culture and Values}

Chung et al. (2011) identify values as important in internalising organisational commitment. Person-organisation fit (i.e. congruency of values, focus, ethos between an employee and the organisation) is highly influential on work performance (Lee \& Bang, 2012). Problems in conservation arise when personal values misalign with organisational purpose, such as upholding animal rights when work involves destroying invasive species (Black et al., 2011). A leader whose team has a strong sense of purpose taps into people's intrinsic motivation (Deming, 1986), relies less on controls, reward and punishment, and instead is able to focus on systemic influences like work design, partnerships, or renewal (Seddon, 2005; Sparrowe, 2005; Black, 2015).

"grounded by our core values and principles, we derive a sense of inner strength and confidence that enhances our effectiveness ... positive feedback, rewards, and recognition for our efforts are welcome sources of validation, (but) we do not have to rely on them ... We (can) move forward even in the absence of support and validation from others" (Froman, 2010).

\subsection{Vision}

Vision is emphasised in "transformational leadership" (Zaccaro \& Banks, 2001; Kouzes \& Posner, 2007) but little research presents its benefits, nor how vision is best created. Boyatzis, Rochford, \& Taylor (2014) link vision-creation and followers' psychological stimulation and suggest vision-building should involve a diverse group of stakeholders to ensure shared priorities. Visioning is an acquired skill, yet training has limited effect (Frese, Beimel, \& Schoenborn, 2003) and little impact on other leadership skills. Creating an inspirational vision was considered among the most important leadership competencies on two surveys of conservation professionals (Bruyere, 2015; Englefield et al., 2019). Straka et al. (2018) emphasise the need to engage others including wider stakeholders in vision building in order to make this relevant. Vision means little on its own or in the absence of action, needing skills found elsewhere in Black et al.'s (2011) framework.

\subsection{Knowledge}

In the wildlife conservation sector, the degrees of knowledge which inform the work range from scientific fact to uncertainty (Black \& Copsey, 2014). Theories of knowledge concern what we know through competence, personal acquaintance, or information (Lehrer, 2015) including beliefs, assumptions, guesswork, and unknowns (Deming, 1993). King \& Kitchener's (2004) ten-year study involving 1700 participants identified that if problems cannot be solved with cer- 
tainty people need the ability to apply reflective judgement. Reflection allows acceptance of uncertainty without immobilizing thinking, so decisions, problem-solving and judgements can be made. Organisations seek information to support decisions, interpret the environment (e.g. market developments), and to learn and improve (Choo, 1996). These processes are influenced by knowledge perceptions and interpretation of information, an area of learning for conservation managers (Knight et al., 2019).

\subsection{Performance Measurement}

Performance measurement quantifies action (Neely, Gregory, \& Platts, 1995; De Toni \& Tonchia, 2001) and should include outcomes and processes (capability of achieving outcomes). Some metrics can be mathematically linked to outcomes (e.g. income), others cannot (e.g. customer satisfaction). Errors in performance measurement include short-termism, historical emphasis not prediction, lack of strategic focus or integration, overall sub-optimisation caused by local optimisation, comparisons instead of improvements, and data overload (Neely, 1999).

Performance in most jobs is restricted by inherent variations in the system and the rules of work (Seddon, 2005). In a few roles elite performers do disproportionately well (e.g. sports, entertainment) and in such cases performance follows Pareto's 80/20 rule (O’Boyle \& Aguinis, 2012). Whichever is the case, leaders must ensure truly exceptional work, rather than lucky performance, is rewarded (Deming, 1986). Correct performance metrics prevent people from being diverted from purposeful work towards superficial efforts or manipulative "gaming" to gain recognition. Evidence of this problem is already observed in healthcare (Lilford et al., 2004), contracting (Baker, 1992), and policing (Patrick, 2009).

Focus on "good" or "bad" results at a point in time is an unreliable test of results (Öberg et al., 2016). The same is true for process audits (e.g. inspections) since it takes no account of trends or contributing factors (Seddon, 2005) and similar problems occur with aggregated indicators ("KPIs") or arithmetic means (Deming, 1986). Öberg et al. (2016) demonstrate that managers better understand performance and improve their decisions by examining variation in longitudinal data. There is already evidence in conservation management, particularly in natural resource management and environmental protection that this type of treatment of data is beneficial (Black \& Leslie, 2018; Gove et al., 2013; Morrison, 2008).

\subsection{Goal-Setting}

Goal-setting is a thoroughly-researched area in organisation behaviour (Miller \& Weiss, 2015) evidenced by strong effects. Performance increases as goal difficulty increases, to a point when difficulty exceeds perceived feasibility by the worker (Kleingeld et al., 2011; Locke \& Latham, 1990, 2002; Wofford et al., 1992). Specific goals are better than vague expectations (Miller \& Weiss, 2015). However, participative goal-setting and impact of feedback are less researched. 
Evolutionary psychology suggests that humans have an array of "proximal" goals (Nicholson, 2008) including wellbeing, altruism, and being trusted. In work, goals tend not to focus on social elements, are often short-term, and sometimes incongruent with organisational purpose and vision (Nicholson, 2008). In short, goal-setting at work is a poor reflection of evolved human goal-perception. To enable improvement, people should collaborate on super-ordinate (team) goals, but also be interdependent in reaching personal goals (Hülsheger, Anderson, \& Salgado, 2009). Goal design and the level they are set (organisation, team, individual) is critical and a focus on the use of overarching conservation programme goals appears to be important Black et al. (2011).

\subsection{Planning}

Planning appears under-represented in psychological literature despite its assumed importance to leaders (Covey, 1992; Kouzes \& Posner, 2007). Traditional planning carries the assumption "that it's possible to figure out most of the unknowns of a business in advance" (Blank, 2013). Importantly, this assumption does not fit with conservation which is characterised by uncertainty (Black \& Copsey, 2014; Mahajan et al., 2019) and relies heavily on experimentation (Black et al., 2013). Studies suggest that planning should be associated with the use of performance information, but only if managers can choose and change performance indicators (Kroll, 2013). Data use in planning is influenced by social norms and managers' attitudes (Kroll, 2013), so conservation leaders must establish a culture of experimentation and data use as a norm (Black et al., 2011). "Lean innovation" accelerates operationalisation of ideas into concrete outcomes (Reis, 2011) and this mirrors Deming's (1986) Plan-Do-Check-Act learning cycle (Harms, 2015) so suits nature conservation and its experimental context better than traditional linear planning.

Deming $(1986,1993)$ and others (Scholtes, 1997; Seddon, 2005) repeatedly assert that putting data in the hands of people doing the work allows continual improvement. Since Kroll (2013) suggests that data use is influenced by mind-set, this explains the importance of a leader's attitude to performance information (Ammons \& Rivenbark, 2008). Conservation leaders must consciously select staff whose mind-set supports data-informed planning and decision-making and fits the culture of the programme.

\subsection{Governance}

Governance, authority and management have been scrutinised in conservation (Clark et al., 1994; Black et al., 2011; Bruyere, 2015), yet few psychology articles explore the topic. Analysis of the rules of governance (environment, psychology, language, procedures, boundaries, group dynamics) show that psychological agency of players (e.g. project manager, funders, community elders) interacts with institutional structures and procedures (Potter \& Hepburn, 2010). Similarly, influences on decision-making are identified as: the board's characteristics 
(demography, knowledge, skills), board processes (effort, conflict, activity), board outcomes (tasks, cohesiveness) and organisational outcomes (Forbes \& Milliken, 1999). These are elements under the direct influence of conservation leaders and should be proactively managed.

Community governance is increasingly important in complex circumstances which cannot be regulated by contracts or law and is a feature often encountered in conservation programmes. Where community governance is needed to change socio-economic norms (e.g. natural resource use, as commonly encountered in conservation) then mismatches in structures of privilege (including class), economics, and reward (i.e. balances in "what's in it for us") will limit the ability for governance to facilitate problem-solving (Bowles \& Gintis, 2002). Leaders should: 1) choose members carefully, and provide an explicit role purpose for each participant; 2) establish clear decision-making processes, with well-defined goals and consequences; 3) develop productive norms (e.g. rules) for board members (Cascio, 2004).

\section{Hands-on Leadership}

The second area of capability in Black et al.'s (2011) framework concerns how leaders go about their role and the nature of their interactions with people doing the work, through "Hands-on Leadership". Black et al. (2011) assert that a hands-on, involved leadership approach which seeks to understand work, data, constraints and realities of a conservation programme are important. This includes having a sound and sensible applied cultural understanding (Straka et al., 2018) of the people and social communities in which the conservation work is undertaken (employees, volunteers or affected stakeholders) and where conservation and poverty alleviation goals exist within the programme (Opfer \& Black, 2019). This is an area of weakness in current design of conservation programmes (Straka et al., 2018). For Black et al. (2011), this understanding also influences whether a leader is best able to develop and communicate appropriate vision, plans and goals as well as engage with and work best alongside people.

\subsection{Involvement and Empowerment}

Empowerment enables self-determining people (i.e. employees) to be creative and energised (Ryan \& Deci, 2000). Froman (2010) discusses involvement and "flow", namely engaging in intrinsically satisfying activities (Csikszentmihalyi, 1991) to enable more productive work. In discussions with executives Quinn \& Spreitzer (1997) differentiated top-down empowerment and bottom-up (organic) "empowerment". Top-down involves clarifying the organization's direction; specifying tasks, roles, and rewards for employees; delegating responsibility; and making people accountable for results. This gets people to comply, but no more and does not tap into the previously mentioned self-determining psychological state of "flow".

The alternative organic approach involves first understanding the needs of 
employees; leaders' then modelling empowered behaviour; teambuilding to encourage cooperation; enabling intelligent risk-taking; and trusting people to perform (Quinn \& Spreitzer, 1997). The latter method matches learning and innovation approaches identified in this review. Empowering people increases capacity within the team and frees up the leader to tackle systemic issues and constraints (Seddon, 2005; Sparrowe, 2005). Quinn \& Spreitzler (1997) state that "It is nearly impossible for unempowered people to empower others". If a leader wants the team to take responsibility and make independent judgements, then they must influence that culture of behavioural norm to be established through the organisation.

\subsection{Questioning and Listening}

Few studies address a leader's listening skills, and instead tend to concern the behaviour of followers De Cremer \& Wubben (2010). Even if the search is expanded, "Psychology and Listening" (with topic filters of Management, Business, Psychology, Experimental Psychology, Applied Psychology, Neuroscience) give a return of 61 articles of which $10 \%$ are thought relevant (most concern music, computer simulation and artificial intelligence).

Authentic listening influences the creative and emotional effort that people put into work (Clegg et al., 2002). Schein (2009) calls this "humble enquiry", where people trust the leader enough to share what they really think and feel. A more stylised approach to questioning and listening is Revans' (1971) “Action Learning" where a team follows a structured process to eliminate hierarchy, power, plausibility, and groupthink. Black \& Copsey (2014) suggest that follower trust, freedom to make decisions, openness, and attention of the leader are important with the latter expressed both in listening and appropriate questioning and Knight et al. (2019) advocate that humility is also fundamental to including stakeholders in collaborations, acknowledging the validity of different values and perspectives.

\subsection{Cultural Sensitivity}

Cultural aspects of conservation leadership appear to be underrepresented in the literature (Straka et al., 2018). This is a significant shortfall since management studies have found that cultural insensitivity by leaders can break the psychological contract with employees (Restubog et al., 2007). Effective work behaviour can be disrupted or offence may even drive deviant anti-organisation behaviour. Robinson \& Bennett (1997: p. 17) note that "whether a given provocation leads to deviant action depends on the presence of constraints or controls that inhibit behaviour". Various safeguards (constraints) can prevent problems, for example organizational values and expectations (norms), team bonding, and sanctions (Restubog et al., 2007). People's response will depend on the level of collectivism in the local culture. However, these parameters and conditions of employment must be clear at the outset, to establish the psychological contract. 
Potential cross-cultural aspects of leadership arise indirectly in other research. For example, Chung et al. (2011) identified that unconventional behaviour by leaders (to get people on their side) becomes dysfunctional when the behaviour deviates from what followers expect, for example, a lack of concern for conventional morality and harmony. Chung et al. (2011) suggest that leaders should avoid unconventional behaviour when encouraging commitment from employees from other cultures. Inter-cultural training may assist assimilation of relevant sensitivities (Knott, Mak, \& Neill, 2013) and increased familiarity and cross-cultural competencies generally also appear valuable in fitting with normal demands of the workplace.

\subsection{Delegation}

Delegation relates to governance structures and levels of authority throughout an organisation (see 3.7). In a typical psychological study of 259 MBA students in the USA the quality of the social exchange between leader and subordinate was shown to be critical in relating leader behaviours and important outcomes (Hassan et al., 2013). Ethical and empowering leader behaviours are reflected in how much followers trust that leader and this research suggests that managers can utilise empowering behaviours to develop relationships that benefit organizational outcomes. Supportive behaviours, coaching and eventual delegation of work to staff reflects situational leadership (Hersey \& Blanchard, 1979; Hersey, Blanchard, \& Natemeyer, 1979). Of course, suitable delegation relates to the capability of the people given the work and for conservation leaders, Black et al. (2011) relate this back to the leader's understanding of the work and clarity on the competence and commitment (or indeed lack of capability or negligence) of staff.

\section{Details and Big Picture}

The third area of capability in Black et al.'s (2011) framework addresses how leaders gain a sense of reality about the constraints and concerns in their programme through a balanced understanding of the details and the bigger picture. This relates to their mental and intellectual perception of the system of work, rather than the practical interactions with people as discussed in the previous "Hands-on Leadership" section. There appears to be a systemic link between high level financial planning, decision-making, partnership building and specific practical challenges of conservation work (Black et al., 2011; Black \& Copsey, 2014; Mahajan et al., 2019) which often involves the management of change in infrastructure, landscapes, resource use, behaviour and ecosystems. Higgs \& Rowland (2011) explored implementation of change, finding that successful leaders stood out as very self-aware and reflective, knowing how to use their presence and behaviour. This type of leader can work "in the moment", put aside personal interests and reactions and focus their attention on what is happening, noticing repeating behaviours or issues and highlighting these to others. 
Those successful leaders kept "in tune with the bigger picture within which the change was positioned and ensured that their team considered their actions and plans in the light of this" (Higgs \& Rowland, 2011). Effective leaders keep change processes clearly connected to the wider picture by showing others that broader context and facilitating individual, team, and organizational learning. This aligns with the third section of Black et al.'s (2011) framework.

\subsection{Problems and Anticipation}

Problems are an inevitable part of life, so it would be sensible to expect humans to have evolved suitable coping mechanisms (Smith, 1975). Problems may be human, work or context related and have been discussed previously in various guises (behaviours, mistakes, learning, plans, culture, performance, governance). Problem definition combines anticipation, data acquisition, planning and analysis (Deming, 1986). Studies by Hunter et al. (2011) and Waldman (2013) identify how leaders' mis-perceptions of problems can cause errors in knowledge acquisition, performance measurement, information interpretation, sense of reality, managing people, resources, problem perception and problem solving. In this respect, human problems like conflict or distress require responses from the "effectively functioning human being" of positive psychology (Sheldon \& King, 2001; Martin, 2005) involving mental processes including adaptation, perceptions, emotions, expectations, resilience, potential, and motivation. Use of longitudinal datasets in conservation will enable analytical methods to understand the predictability (or expected unpredictability at worst) of the state of ecosystems to anticipate if intervention is required or not (see 3.4 above and 6.1 below).

\subsection{Budgets and Finance}

Only one article relating to the psychology of budgets and resources arose in the search. Nevertheless, finances and resources are a key focus (cognitive interest) in management. It is important that managers (leaders) are involved in budget development, if not, their responsibility for budget control becomes ambiguous and erodes job satisfaction (Chenhall \& Brownell, 1988). Leaders could consider how to involve their team in budget development since research suggests that team participation leads to better budgets, will facilitate employee performance, increase organizational commitment and raise job performance (Nouri \& Parker, 1998).

Leaders need to be careful not to play games with budgets. Literature in cognitive psychology provides evidence which suggests that resource constraints appear to stimulate creativity, innovative behaviour and resourcefulness (Weiss, Hoegl, \& Gibbert, 2011). However, their research also warns that neither resource abundance nor scarcity are reliable factors for managerial control of innovation (i.e. intentional withdrawal of resource to increase innovation).

On the other side of the financial "coin" is accessing funds. Leaders (in con- 
servation at least) have responsibilities for cultivating relationships with funders which includes strategies established by research (Waters, 2009), namely: openness (most important for donors), task sharing (next most important, covering funders' assistance with service provision, training etc.), assurance (commitments to maintain the relationship), access (being visible to funders), positivity, and networking. A key finding from Waters' (2009) research is that leaders should regularly dialogue with donors to understand the emphasis to place across these six strategies.

\subsection{Partnerships}

Skills at partnership-building were rated as the most important attribute for conservation leadership in Bruyere's (2015) study of conservation leaders. However, the search for partnerships gave no returns in Web of Science, so a revised term "collaboration" was used to identify a few relevant studies.

Covey (1992) discusses the need for a win-win mentality in building collaborations with others and this has also been discussed in conservation literature (Redpath et al., 2013). Revealing research by Kelman \& Hong (2012) on social services, policing and education partnerships draws out the importance of "hard" (i.e. assertive) approaches in multi-agency collaborations: 1) Initiating Structure (e.g. A good safety manager will seek to exert considerable influence over partnership actions); 2) Accountability (e.g. the executive board questions performance information, rather just hearing presentations or reports); 3) Direction (If leaders have problems getting engagement from a statutory partner, they do not hesitate to remind them of legal responsibilities).

These approaches are different to common "softer" approaches such as "listening to others", "working out problems together", "being open to new ideas", "showing empathy" or "avoiding contentious subjects", "inclusive decision making", "promoting a shared vision" and "promoting a warm and positive working climate". It is interesting that Kelman \& Hong's (2012) research identifies that the "harder" approach is a necessary foundation for strength and integrity of collaborative behaviours.

\section{Improvement and Learning}

The final area of capability in Black et al.'s (2011) four-part framework addresses improvement and learning and relates to both knowledge development and application of knowledge to improve the work and the results which are achieved. This is an important set of feedback processes which engages leaders with new knowledge to sustain the effectiveness of their organisation, particularly important in emerging or changing contexts common in conservation work. These concepts relate to the "learning culture" that is advocated for adaptive, agile organisations (Senge, 2006). Since Black et al.'s (2011) initial assertions about learning, the literature in the conservation sector now increasingly raises the issue of learning and improvement (see Martin et al., 2012; Catalano et al., 2018; 
Knight et al., 2019) but there is still much to learn from wider management and psychological literature.

\subsection{Capability}

Capability concerns the predictability of work processes or people to deliver outputs (Porter \& Oakland, 1991). Goals focus on "the now", but capability considers overall (and future) performance (Nicholson, 2008) an area often ignored in leaders' short-term priorities. Capability can be calculated from performance data to inform decisions, differentiating random changes from attributable (known-cause) variation (Shewhart, 1931) and can be applied to conservation management (Leslie et al., 2017).

When we consider human capabilities, once considered innate talents (e.g. musical skill), we know understand that they actually arise from intense practice (Ericsson et al., 1993). At work, time to develop skills is influenced by the people's potential as seen by leaders and the encouragement leaders provide (Martin, 2005). Lee \& Bang (2012) identified that respecting staff as capable individuals, increases staff commitment and trust of managers; both linked to improved performance. There is a strong positive relationship between self-efficacy (how you think you perform) and performance (Stajkovic \& Luthans, 1998). The efficacy-performance link is aided by clear tasks, resources, and a workplace free from distractions. If people can collect performance feedback, feel some control over work and care about the consequences of performance, they will learn to be more effective (Bandura, 1997; Brannick et al., 1997; Stajkovic \& Luthans, 1998).

\subsection{Experimentation and Innovation}

Innovation is critical in conservation since often situations are encountered for the first time. In mainstream management literature Norbom \& Lopez (2016) identified that leaders influence innovation by "being deeply knowledgeable, having access to important and useful connections inside and outside the organization, and being role models who are able to engender a strong sense of belonging and supportiveness among others". This links to trust and permission to innovate which at work typically comes from people's manager and colleagues (Boyatzis, 2008).

Clegg et al. (2002) identified that the level at which people thought the organisation takes ideas seriously is a predictor of actual idea generation by workers. This is also associated with implementation of ideas. However, a belief that the organisation has people's interests at heart is associated with actual levels of suggestions (Clegg et al., 2002). The more people feel they are listened to seriously, the more effort they put into implementing ideas. Eisenbeiss, van Knippenberg, \& Boerner (2008) identified that leaders' encouragement of innovation only has impact if there are organisational norms for high standards. The same emphasis is made by Black et al. (2011) for leaders to encourage pursuit of 
alternative solutions and expect high standards of performance. Modern lean innovation (Reis, 2011; Blank, 2013) utilises the scientific cycle (Deming, 1986). Innovation, experimentation, error management, learning and improvement draw on consistent theory, so Black et al.'s (2011) framework aligns these constructs correctly.

\subsection{Error Management}

Deming (1986) implores leaders to drive out fear and blame which reduce people's creativity and undermines commitment. Recrimination also incentivises people to hide errors and thereby retain problems inside the organisation (Seddon, 2005). In high uncertainty environments with a propensity for error (such as conservation) Hunter et al. (2011) suggest that leaders categorize errors most critical to the system, versus others better viewed as "acceptable risks". Hunter et al. (2011) recommend an "error management" culture, where people learn from failures or mistakes and use the knowledge to stimulate innovation. This aligns with Catalano et al.'s (2018) assertion that a "learning from failure" culture is vital for the complex contexts of wildlife conservation problems and is also a requirement to encourage experimentation.

Handling mistakes and failure is also likely connected to the notion of leadership wisdom as suggested by Knight et al. (2019). In their discussion appraising conservation interventions they suggest that "conservation biology has often gathered data and information at the expense of generating knowledge and wisdom". This observation is matched by Black et al.'s (2011) recommendation for leaders to make particular effort to enable staff "to challenge, share, and learn from mistakes ... Appraise the system ... learn from failures”.

\subsection{Learning}

High standards of learning are maintained by mutual support of ideas by staff and management alongside mutual monitoring and critical appraisal (Hülsheger, Anderson, \& Salgado, 2009). Leaders need to encourage dissent to overcome groupthink and enable innovation, whilst teams must be capable of reflective judgement and open to divergent thinking (Dreu, 2002). Openness, learning, critique, and support reflect the "Learning Organisation" (Senge, 2006).

A study of students (Cohen, Darnon, \& Molaret, 2017) differentiates mastery goals (desire to learn) from performance goals and suggests that learning-related goals are more socially desirable than performance goals (which usually focus on individuals). A learning environment may benefit team members' commitment more than individual performance-focused culture. Celik et al. (2016) found that work-related curiosity was a positive predictor of a worker's innovation in a sample of 480 participants in 188 different jobs. This study provides evidence of the importance of personality traits in creative work behaviour. If a leader needs a creative, innovative team, then curiosity would be one important trait to test during recruitment. 


\subsection{Training}

Clearly the effectiveness of the design of specific training (whether on-the-job or outside-work) will relate to the degree to which the intervention can be evaluated for impact on expected internal performance (e.g. process performance or organisational payoff) or external requirements, such as societal contributions (Kaufman et al., 1995), or in the case of conservation, biodiversity improvements. Aside from direct skill acquisition, at the level of the individual employee, evidence from Korean NGOs suggests that training can also align employees' values and motivation (Park \& Kim, 2016), nurturing constructive social exchange relationships evidenced by people being able to participate in decision making. For those Korean workers, their self-perceptions and intrinsic motivation were strengthened. This clearly relates to leadership influence on performance and identity with the organisation.

Further to individual effectiveness, experiential learning of team processes is beneficial to team performance (Wildman \& Bedwell, 2013), enables people to become self-managing and thereby strengthens team identity. Voegtlin, Boehm, \& Bruch (2015) found a positive association between training and collaborative empowerment for a sample of over 2000 employees in a multinational company. They examined empowerment, self-assessment, and group communication and found that training helped establish a suitable culture with positive effects on employee perception. Training itself, therefore, has a role in leadership processes that go beyond capability, but into social norms around learning and improvement, empowerment and team culture.

\section{Findings}

This review has raised a vast array of leadership constructs. Research suggests that few people have a suitable variety of skills to carry out the multiple roles associated with leadership effectiveness (Kaplan \& Kaiser, 2010) and "de-railed" executives (i.e. capable, ambitious managers who nonetheless fail) tend to lack these characteristics and capabilitires (Van Vugt et al., 2008). This problem has also been observed in cases of failed conservation leadership (Clark et al., 1994; Black \& Copsey, 2014). Mainstream leadership studies identify that power increases leaders' potential for abuse and decreases empathy for subordinates (Kipnis, 1972; Gruenfeld et al., 2008). Ethnographers also reveal that most managers understand that pleasing their boss is more important to career success than pleasing subordinates (Van Vugt et al., 2008), so without care leaders can easily cultivate negative approaches that followers subsequently resent. Clearly, this will erode trust towards those leaders.

Modern leadership psychology (Van Vugt et al., 2008) suggests instead the importance of integrity (trustworthiness), persistence (steadiness under adversity), humility (group placed ahead of personal ambitions), competence (leaders are resources for their groups), decisiveness (timely and defensible decisions), and vision (providing inspiration), involving engagement of staff and facilitation 
(Cooper et al., 2005; Higgs \& Rowland, 2011). Since recent research has identified difficulties in the conservation sector relating to gender equality, such as exclusion from opportunity, prejudiced perceptions of incapability, and harassment (Jones \& Solomon, 2019) the importance of improved, modern skill sets and mindsets of conservation leadership appear even more imperative to improve leader perception, self-efficacy, intervention, relationships and general work culture. In addition, under the pressure of change (which is a common focus for wildlife conservation) there is evidence that a leader should be able to shift focus to wider systemic issues (Bryman, 1992; Kouzes \& Posner, 2007), since success emerges through influences upon many factors in the overall system. Kilburg \& Donohue's (2011) "grand theory" of leadership describes six components: external environment, the diverse characteristics of people, the diverse perceptions and behaviour of those people (especially their purpose, direction and approach), working relationships, organizational systems and organizational performance. This review illustrates that all of these components align with Black et al.'s (2011) framework. It is notable that all of these concepts feature in psychological studies relating to leadership (Figure 1). This review also identifies interactions which exist between the four areas in the conservation leadership framework as illustrated in Figure 2.

\section{Summary}

This review has drawn on a wide range of psychological studies within the scope of a published leadership framework for the under-researched arena of

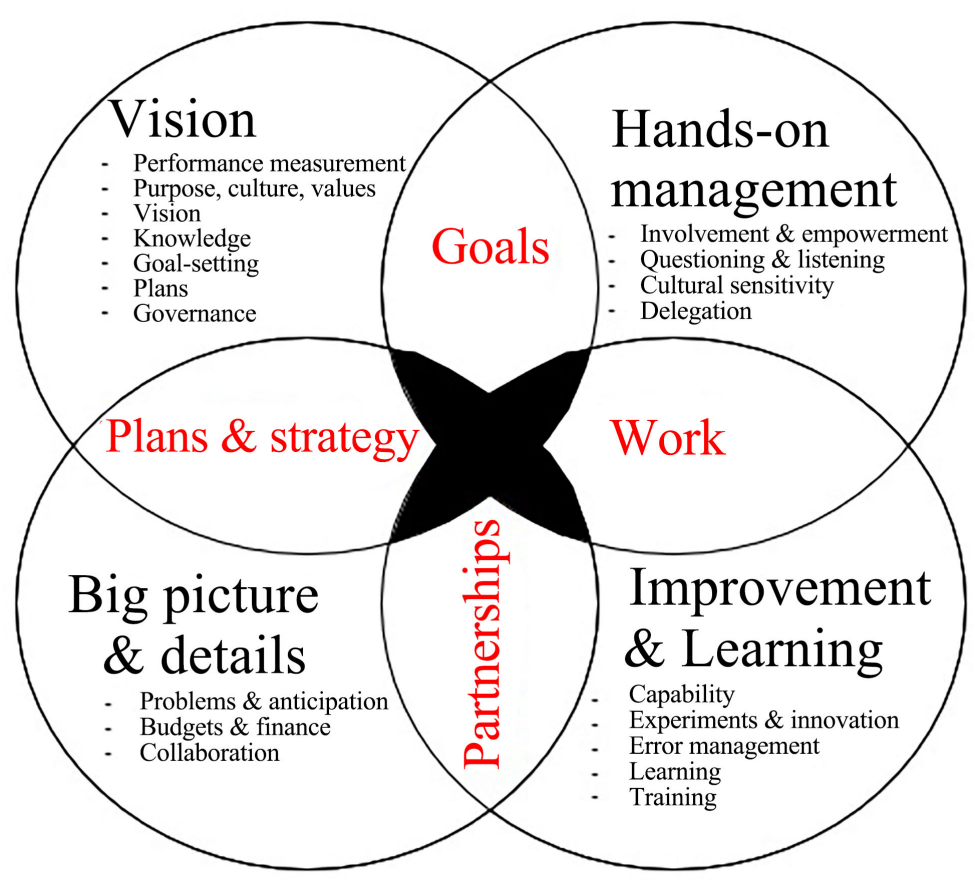

Figure 2. Interactions between four areas of the conservation leadership framework (Black et al., 2011) as examined in this review of psychology literature (adapted from Copsey et al., 2018). 
wildlife conservation leadership. The suggested areas of capability discussed by Black et al. (2011) remain a robust guide within the context, constraints and challenges of wildlife conservation leadership. Furthermore, the tenets of Black et al.'s (2011) framework are shown to be represented and supported by contemporary knowledge, fitting the "New Psychology of Leadership" (Haslam \& Reicher, 2016) and suggests that the assertions made for conservation leaders remain relevant:

1) Provide clarity and agreement on purpose, vision and goals;

2) Define organisational boundaries and capacity to influence externally;

3) Be sensitive to people, their culture, expectations, strengths and identity;

4) Have confidence to engage dissent and people with alternative views;

5) Work alongside people in cooperation and partnership;

6) Give people more control through clear governance and flexible plans;

7) Inform decisions with data, and learn from failures without blame;

8) Recognise and celebrate success and encourage pursuit of improvements.

\section{Conflicts of Interest}

The authors declare no conflicts of interest regarding publication of this paper.

\section{References}

Ammons, D., \& Rivenbark, W. (2008). Factors Influencing the Use of Performance Data to Improve Municipal Services: Evidence from the North Carolina Benchmarking Project. Public Administration Review, 68, 304-331. https://doi.org/10.1111/j.1540-6210.2007.00864.x

Ajzen, I. (1991). The Theory of Planned Behavior. Organizational Behavior and Human Decision Processes, 50, 179-211. https://doi.org/10.1016/0749-5978(91)90020-T

Baker, G. P. (1992). Incentive Contracts and Performance Measurement. Journal of Political Economy, 100, 598-614. https://doi.org/10.1086/261831

Bandura, A. (1997). Self-Efficacy. The Exercise of Control. New York: Freeman.

Bass, B. M. (1997). Does the Transactional-Transformational Leadership Paradigm Transcend Organizational and National Boundaries? American Psychologist, 52, 130. https://doi.org/10.1037//0003-066X.52.2.130

Bengston, D. N., \& Fan, D. P. (1999). An Innovative Method for Evaluating Strategic Goals in a Public Agency Conservation Leadership in the US Forest Service. Evaluation Review, 23, 77-100. https://doi.org/10.1177/0193841X9902300104

Bianco, M., Koss, R., \& Zischka, K. (2016). Empowering Emerging Leaders in Marine Conservation. Aquatic Conservation: Marine and Freshwater Ecosystems, 26, 225-236. https://doi.org/10.1002/aqc. 2650

Black, S. A., \& Copsey, J. A. (2014). Does Deming's "System of Profound Knowledge" Apply to Leaders of Biodiversity Conservation? Open Journal of Leadership, 3, 53-65. https://doi.org/10.4236/ojl.2014.32006

Black, S. A., Groombridge, J. J., \& Jones, C. G. (2011). Leadership and Conservation Effectiveness: Finding a Better Way to Lead. Conservation Letters, 4, 329-339. https://doi.org/10.1111/j.1755-263X.2011.00184.x

Black, S. A., Groombridge, J. J., \& Jones, C. G. (2013). Using Better Management Thinking to Improve Conservation Effectiveness. ISRN Biodiversity, 2013, Article ID: 
784701. https://doi.org/10.1155/2013/784701

Black, S. A., \& Leslie, S. C. (2018). Understanding Impact of Mitigation Action through Waterway Control Systems on Manatee Deaths in Florida. International Journal of Avian \& Wildlife Biology, 3, 386-390. https://doi.org/10.15406/ijawb.2018.03.00124

Black, S. A. (2015). A Clear Purpose Is the Start Point for Conservation Leadership. Conservation Letters, 8, 383-384. https://doi.org/10.1111/conl.12203

Blank, S. (2013). Why the Lean Start-Up Changes Everything. Harvard Business Review, 91, 63-72.

Bowles, S., \& Gintis, H. (2002). Social Capital and Community Governance. The Economic Journal, 112, F419-F436. https://doi.org/10.1111/1468-0297.00077

Boyatzis, R. E. (2008). Leadership Development from a Complexity Perspective. Consulting Psychology Journal: Practice and Research, 60, 298.

https://doi.org/10.1037/1065-9293.60.4.298

Boyatzis, R. E., Rochford, K., \& Taylor, S. N. (2014). The Role of the Positive Emotional Attractor in Vision and Shared Vision: Toward Effective Leadership, Relationships, and Engagement. Frontiers in Psychology, 6, 670.

https://doi.org/10.3389/fpsyg.2015.00670

Brannick, M. T., Salas, E., \& Prince, C. W. (1997). Team Performance Assessment and Measurement: Theory, Methods, and Applications. Hove: Psychology Press.

https://doi.org/10.4324/9781410602053

Bruyere, B. L. (2015). Giving Direction and Clarity to Conservation Leadership. Conservation Letters, 8, 378-382. https://doi.org/10.1111/conl.12174

Bryman, A. (1992). Charisma and Leadership in Organizations. Thousand Oaks, CA: Sage Publications.

Cannon, J. R., Dietz, J. M., \& Dietz, L. A. (1996). Training Conservation Biologists in Human Interaction Skills. Conservation Biology, 10, 1277-1282.

https://doi.org/10.1046/j.1523-1739.1996.10041277.x

Cascio, W. F. (2004). Board Governance: A Social Systems Perspective. The Academy of Management Executive, 18, 97-100. https://doi.org/10.5465/ame.2004.12689560

Case, P., Evans, L. S., Fabinyi, M., Cohen, P. J., Hicks, C. C., Prideaux, M., \& Mills, D. J. (2015). Rethinking Environmental Leadership: The Social Construction of Leaders and Leadership in Discourses of Ecological Crisis, Development, and Conservation. Leadership, 11, 396-423. https://doi.org/10.1177/1742715015577887

Catalano, A. S., Redford, K., Margoluis, R., \& Knight, A. T. (2018). Black Swans, Cognition, and the Power of Learning from Failure. Conservation Biology, 32, 584-596. https://doi.org/10.1111/cobi.13045

Celik, P., Celik, P., Storme, M., Storme, M., Davila, A., Davila, A., \& Myszkowski, N. (2016). Work-Related Curiosity Positively Predicts Worker Innovation. Journal of Management Development, 35, 1184-1194. https://doi.org/10.1108/JMD-01-2016-0013

Chenhall, R. H., \& Brownell, P. (1988). The Effect of Participative Budgeting on Job Satisfaction and Performance: Role Ambiguity as an Intervening Variable. Accounting, Organizations and Society, 13, 225-233. https://doi.org/10.1016/0361-3682(88)90001-3

Choo, C. W. (1996). The Knowing Organization: How Organizations Use Information to Construct Meaning, Create Knowledge and Make Decisions. International Journal of Information Management, 16, 329-340. https://doi.org/10.1016/0268-4012(96)00020-5

Chung, A., Chen, I. H. et al. (2011). Charismatic Leadership and Self-Leadership: A Relationship of Substitution or Supplementation in the Contexts of Internalization and Identification? Journal of Organizational Change Management, 24, 299-313. 
https://doi.org/10.1108/09534811111132703

Clark, T. W., Reading, R. P., \& Clarke, A. L. (1994). Endangered Species Recovery: Finding the Lessons, Improving the Process. Washington DC: Island Press.

Clark, T. W. (2001). Developing Policy-Oriented Curricula for Conservation Biology: Professional and Leadership Education in the Public Interest. Conservation Biology, 15, 31-39. https://doi.org/10.1111/j.1523-1739.2001.99007.x

Clegg, C., Unsworth, K., Epitropaki, O., \& Parker, G. (2002). Implicating Trust in the Innovation Process. Journal of Occupational and Organizational Psychology, 75, 409-422. https://doi.org/10.1348/096317902321119574

Cohen, J., Darnon, C., \& Mollaret, P. (2017). Distinguishing the Desire to Learn from the Desire to Perform: The Social Value of Achievement Goals. The Journal of Social Psychology, 157, 30-46. https://doi.org/10.1080/00224545.2016.1152216

Cooper, C. D., Scandura, T. A., \& Schriesheim, C. A. (2005). Looking Forward But Learning from Our Past: Potential Challenges to Developing Authentic Leadership Theory and Authentic Leaders. The Leadership Quarterly, 16, 475-493.

https://doi.org/10.1016/j.leaqua.2005.03.008

Copsey, J. A., Black, S. A., Groombridge, J. J., \& Jones, C. G. (2018). Species Conservation: Lessons from Islands (pp. 248-250). Cambridge: Cambridge University Press. https://doi.org/10.1017/9781139030243

Covey, S. R. (1992). Principle Centered Leadership. New York: Simon and Schuster.

Crandall, J. E., \& Rasmussen, R. D. (1975). Purpose in Life as Related to Specific Values. Journal of Clinical Psychology, 31, 483-485.

https://doi.org/10.1002/1097-4679(197507)31:3<483::AID-JCLP2270310326>3.0.CO;2$\underline{\mathrm{C}}$

Csikszentmihalyi, M. (1991). Flow, the Psychology of Optimal Experience, Steps towards Enhancing the Quality of Life. New York: Harper \& Row, Publishers.

De Cremer, D., \& Wubben, M. (2010). When Does Voice Have to Be More Than Only Listening? Procedural Justice Effects as a Function of Confident Leadership. Journal of Personnel Psychology, 9, 69-78.

De Toni, A., \& Tonchia, S. (2001). Performance Measurement Systems-Models, Characteristics and Measures. International Journal of Operations \& Production Management, 21, 46-71. https://doi.org/10.1108/01443570110358459

Deming, W. E. (1986). Out of the Crisis. Cambridge, MA: MIT Center for Advanced Engineering Studies.

Deming, W. E. (1993). The New Economics (240 p). Cambridge, MA: Massachusetts Institute of Technology, Center for Advanced Engineering Study.

Dietz, J. M., Aviram, R., Bickford, S., Douthwaite, K., Goodstine, A., Izursa, J. L., \& Parker, K. (2004). Defining Leadership in Conservation: A View from the Top. Conservation Biology, 18, 274-278. https://doi.org/10.1111/j.1523-1739.2004.00554.X

Dreu, C. K. D. (2002). Team Innovation and Team Effectiveness: The Importance of Minority Dissent and Reflexivity. European Journal of Work and Organizational Psychology, 11, 285-298. https://doi.org/10.1080/13594320244000175

Eisenbeiss, S. A., van Knippenberg, D., \& Boerner, S. (2008). Transformational Leadership and Team Innovation: Integrating Team Climate Principles. Journal of Applied Psychology, 93, 1438. https://doi.org/10.1037/a0012716

Englefield, E., Black, S. A., Copsey, J. A., \& Knight, A. T. (2019). Interpersonal Competencies Define Effective Conservation Leadership. Biological Conservation, 235, 18-26. https://doi.org/10.1016/j.biocon.2019.03.043 
Ericsson, K. A., Krampe, R. T., \& Tesch-Römer, C. (1993). The Role of Deliberate Practice in the Acquisition of Expert Performance. Psychological Review, 100, 363. https://doi.org/10.1037/0033-295X.100.3.363

Evans, L., Hicks, C. C., Cohen, P. J., Case, P., Prideaux, M., \& Mills, D. J. (2015). Understanding Leadership in the Environmental Sciences. Ecology \& Society, 20, 50. https://doi.org/10.5751/ES-07268-200150

Fiedler, F. E. (1964). A Contingency Model of Leadership Effectiveness. Advances in EXperimental Social Psychology, 1, 149-190. https://doi.org/10.1016/S0065-2601(08)60051-9

Forbes, D. P., \& Milliken, F. J. (1999). Cognition and Corporate Governance: Understanding Boards of Directors as Strategic Decision-Making Groups. Academy of Management Review, 24, 489-505. https://doi.org/10.5465/amr.1999.2202133

French, J., \& Raven, B. (1959). The Bases of Social Power. In D. Cartwright (Ed.), Studies in Social Power (259-269). Ann Arbor, MI: Institute for Social Research.

Frese, M., Beimel, S., \& Schoenborn, S. (2003). Action Training for Charismatic Leadership: Two Evaluations of Studies of a Commercial Training Module on Inspirational Communication of a Vision. Personnel Psychology, 56, 671-698. https://doi.org/10.1111/j.1744-6570.2003.tb00754.x

Froman, L. (2010). Positive Psychology in the Workplace. Journal of Adult Development, 17, 59-69. https://doi.org/10.1007/s10804-009-9080-0

Gove, A. D., Sadler, R., Matsuki, M., Archibald, R., Pearse, S. et al. (2013). Control Charts for Improved Decisions in Environmental Management: A Case Study of Catchment Water Supply in South-West Western Australia. Ecological Management \& Restoration, 14, 127-134. https://doi.org/10.1111/emr.12040

Gruenfeld, D. H., Inesi, M. E., Magee, J. C., \& Galinsky, A. D. (2008). Power and the Objectification of Social Targets. Journal of Personality and Social Psychology, 95, 111. https://doi.org/10.1037/0022-3514.95.1.111

Grint, K. (2005). Leadership: Limits and Possibilities. Basingstoke: Palgrave Macmillan. https://doi.org/10.1007/978-1-137-07058-6

Gutiérrez, N. L., Hilborn, R., \& Defeo, O. (2011). Leadership, Social Capital and Incentives Promote Successful Fisheries. Nature, 470, 386-389.

https://doi.org/10.1038/nature09689

Harms, R. (2015). Self-Regulated Learning, Team Learning and Project Performance in Entrepreneurship Education: Learning in a Lean Startup Environment. Technological Forecasting and Social Change, 100, 21-28. https://doi.org/10.1016/j.techfore.2015.02.007

Haslam, S. A., Reicher, S. D., \& Platow, M. J. (2010). The New Psychology of Leadership: Identity, Influence and Power. Hove: Psychology Press. https://doi.org/10.4324/9780203833896

Haslam, S. A., \& Reicher, S. D. (2016). Rethinking the Psychology of Leadership: From Personal Identity to Social Identity. Daedelus, Journal of the American Academy of Arts and Sciences, 145, 21-34. https://doi.org/10.1162/DAED_a_00394

Hassan, S., Mahsud, R., Yukl, G., \& Prussia, G. E. (2013). Ethical and Empowering Leadership and Leader Effectiveness. Journal of Managerial Psychology, 28, 133-146.

Haubold, E. M. (2012). Using Adaptive Leadership Principles in Collaborative Conservation with Stakeholders to Tackle a Wicked Problem: Imperiled Species Management in Florida. Human Dimensions of Wildlife, 17, 344-356.

https://doi.org/10.1080/10871209.2012.709308 
Henman, P. (2016). Techniques and Paradoxes in Performing Performance Measurements: Concluding Reflections. Policy Studies, 37, 597-609.

https://doi.org/10.1080/01442872.2016.1190447

Hersey, P., \& Blanchard, K. H. (1979). Life Cycle Theory of Leadership. Training and Development Journal, 33, 94-100.

Hersey, P., Blanchard, K. H., \& Natemeyer, W. E. (1979). Situational Leadership, Perception, and the Impact of Power. Group \& Organization Studies, 4, 418-428. https://doi.org/10.1177/105960117900400404

Hersey, P., \& Goldsmith, M. (1980). The Changing Role of Performance Management. Training and Development Journal, 34, $38-44$.

Higgs, M., \& Rowland, D. (2011). What Does It Take to Implement Change Successfully? A Study of the Behaviors of Successful Change Leaders. The Journal of Applied Behavioral Science, 47, 309-335. https://doi.org/10.1177/0021886311404556

House, R. J., Hanges, P. J., Ruiz-Quintanilla, S. A., Dorfman, P. W., Javidan, M., Dickson, M., \& Gupta, V. (1999). Cultural Influences on Leadership and Organizations: Project Globe. Advances in Global Leadership, 1, 171-233.

Hülsheger, U. R., Anderson, N., \& Salgado, J. F. (2009). Team-Level Predictors of Innovation at Work: A Comprehensive Meta-Analysis Spanning Three Decades of Research. Journal of Applied Psychology, 94, 1128. https://doi.org/10.1037/a0015978

Hunter, S. T., Tate, B. W., Dzieweczynski, J. L., \& Bedell-Avers, K. E. (2011). Leaders Make Mistakes: A Multilevel Consideration of Why. The Leadership Quarterly, 22, 239-258. https://doi.org/10.1016/j.leaqua.2011.02.001

Jacobs, C. S. (2009). Management Rewired: Why Feedback Doesn't Work and Other Surprising Lessons from the Latest Brain Science. London: Penguin.

Jones, M. S., \& Solomon, J. (2019). Challenges and Supports for Women Conservation Leaders. Conservation Science and Practice, 1, e36.

Kaplan, R. E., \& Kaiser, R. B. (2010). Toward a Positive Psychology for Leaders. In P. A. Linley, \& S. Harrington (Eds.), Oxford Handbook of Positive Psychology and Work (pp. 107-120, Chapter 9). Oxford: Oxford University Press.

Kaufman, R., Keller, J., \& Watkins, R. (1995). What Works and What Doesn't: Evaluation beyond Kirkpatrick. Performance and Instruction, 35, 8-12.

https://doi.org/10.1002/pfi.4170350204

Kelman, S. J., \& Hong, S. (2012). Hard, Soft, or Tough Love: What Kinds of Organizational Culture Promote Successful Performance in Cross-Organizational Collaborations? Harvard Kennedy School Faculty Research Working Paper Series RWP12-005, John F. Kennedy School of Government, Harvard University. https://dash.harvard.edu/handle/1/8506868

Kilburg, R. R., \& Donohue, M. D. (2011). Toward a “Grand Unifying Theory” of Leadership: Implications for Consulting Psychology. Consulting Psychology Journal: Practice and Research, 63, 6. https://doi.org/10.1037/a0023053

King, P. M., \& Kitchener, K. S. (2004). The Relfectiver Judgement Model: Twenty Years of Research on Epistemic Cognition. In B. K. Hofer, \& P. R. Pintrich (Eds.), Personal Epistemology: The Psychology of Beliefs about Knowledge and Knowing (pp. 37-62). Hove: Psychology Press.

Kipnis, D. (1972). Does Power Corrupt? Journal of Personality and Social Psychology, 24, 33. https://doi.org/10.1037/h0033390

Kleiman, D. G., Reading, R. P., Miller, B. J., Clark, T. W., Scott, J. M., Robinson, J., Wallace, R. L., Cabin, R. J., \& Felleman, F. (2000). Improving the Evaluation of Conserva- 
tion Programs. Conservation Biology, 14, 356-365.

https://doi.org/10.1046/j.1523-1739.2000.98553.x

Kleingeld, A., van Mierlo, H., \& Arends, L. (2011). The Effect of Goal Setting on Group Performance: A Meta-Analysis. Journal of Applied Psychology, 96, 1289-1304. https://doi.org/10.1037/a0024315

Knies, E., Jacobsen, C. B., \& Tummers, L. (2016). Leadership and Organizational Performance: State of the Art and Research Agenda. In Routledge Companion to Leadership (404-418). Abingdon-on-Thames: Routledge.

Knight, A. T., Cook, C. N., Redford, K. H., Biggs, D., Romero, C., Ortega-Argueta, A., Norman, C. D., Parsons, B., Reynolds, M., Eoyang, G., \& Keene, M. (2019). Improving Conservation Practice with Principles and Tools from Systems Thinking and Evaluation. Sustainability Science, 1, 1-18. https://doi.org/10.1007/s11625-019-00676-x

Knott, V. E., Mak, A. S., \& Neill, J. T. (2013). Teaching Intercultural Competencies in Introductory Psychology via Application of the Excellence in Cultural Experiential Learning and Leadership Model. Australian Journal of Psychology, 65, 46-53. https://doi.org/10.1111/ajpy.12008

Kouzes, J. M., \& Posner, B. Z. (2007). The Leadership Challenge (4th ed.). San Francisco, CA: Jossey-Bass Publishers.

Kroll, A. (2013). Explaining the Use of Performance Information by Public Managers: A Planned-Behavior Approach. The American Review of Public Administration, 45, 201-215. https://doi.org/10.1177/0275074013486180

Lee, J. W., \& Bang, H. (2012). High Performance Work Systems, Person-Organization Fit and Organizational Outcomes. Journal of Business Administration Research, 1, 129. https://doi.org/10.5430/jbar.v1n2p129

Lehrer, K. (2015). Theory of Knowledge. Abingdon-on-Thames: Routledge. https://doi.org/10.4324/9780203870198

Leslie, S. C., Blackett, F. C., Stalio, M., \& Black, S. A. (2017). Systems Behaviour Charts for Longitudinal Data Inform Marine Conservation Management. Journal of Aquaculture \& Marine Biology, 6, Article ID: 00171. https://doi.org/10.15406/jamb.2017.06.00171

Lilford, R., Mohammed, M. A., Spiegelhalter, D., \& Thomson, R. (2004). Use and Misuse of Process and Outcome Data in Managing Performance of Acute Medical Care: Avoiding Institutional Stigma. The Lancet, 363, 1147-1154. https://doi.org/10.1016/S0140-6736(04)15901-1

Locke, E. A., \& Latham, G. P. (1990). A Theory of Goal Setting \& Task Performance. Upper Saddle River, NJ: Prentice-Hall, Inc.

Locke, E. A., \& Latham, G. P. (2002). Building a Practically Useful Theory of Goal Setting and Task Motivation: A 35-Year Odyssey. American Psychologist, 57, 705-717. https://doi.org/10.1037/0003-066X.57.9.705

Mahajan, S. L., Glew, L., Rieder, E., Ahmadia, G., Darling, E., Fox, H. E., Mascia, M. B., \& McKinnon, M. (2019). Systems Thinking for Planning and Evaluating Conservation Interventions. Conservation Science and Practice, 1, e44. https://doi.org/10.1111/csp2.44

Manolis, J. C., Chan, K., Finkelstein, M., Stephens, S., Nelson, C., Grant, J., \& Dombeck, M. (2009). Leadership: A New Frontier in Conservation Science. Conservation Biology, 23, 879-886. https://doi.org/10.1111/j.1523-1739.2008.01150.x

Martin, A. J. (2005). The Role of Positive Psychology in Enhancing Satisfaction, Motivation, and Productivity in the Workplace. Journal of Organizational Behavior Management, 24, 113-133. https://doi.org/10.1300/J075v24n01_07 
Martin, T. G., Nally, S., Burbidge, A. A., Arnall, S., Garnett, S. T., Hayward, M. W., Lumsden, L. F., Menkhorst, P., McDonald-Madden, E., \& Possingham, H. P. (2012). Acting Fast Helps Avoid Extinction. Conservation Letters, 5, 274-280. https://doi.org/10.1111/j.1755-263X.2012.00239.x

Mattson, D. J., Clark, S. G., Byrd, K. L., Brown, S. R., \& Robinson, B. (2011). Leaders' Perspectives in the Yellowstone to Yukon Conservation Initiative. Policy Sciences, 44, 103-133. https://doi.org/10.1007/s11077-011-9127-5

Miller, L. E., \& Weiss, R. M. (2015). Setting Goals in Different Roles: Applying Key Results From the Goal-Setting Literature. Organization Management Journal, 12, 14-22. https://doi.org/10.1080/15416518.2014.969367

Morrison, L. W. (2008). The Use of Control Charts to Interpret Environmental Monitoring Data. Natural Areas Journal, 28, 66-73. https://doi.org/10.3375/0885-8608(2008)28[66:TUOCCT]2.0.CO;2

Neely, A., Gregory, M., \& Platts, K. (1995). Performance Measurement System Design: A Literature Review and Research Agenda. International Journal of Operations \& Production Management, 15, 80-116. https://doi.org/10.1108/01443579510083622

Neely, A. (1999). The Performance Measurement Revolution: Why Now and What Next? International Journal of Operations \& Production Management, 19, 205-228. https://doi.org/10.1108/01443579910247437

Nicholson, N. (2008). Evolutionary Psychology, Organizational Culture, and the Family Firm. The Academy of Management Perspectives, 22, 73-84. https://doi.org/10.5465/amp.2008.32739760

Norbom, H. M., \& Lopez, P. D. (2016). Leadership and Innovation: Informal Power and Its Relationship to Innovative Culture. Journal of Leadership Studies, 10, 18-31. https://doi.org/10.1002/jls.21430

Nouri, H., \& Parker, R. J. (1998). The Relationship between Budget Participation and Job Performance: The Roles of Budget Adequacy and Organizational Commitment. Accounting, Organizations and Society, 23, 467-483. https://doi.org/10.1016/S0361-3682(97)00036-6

Öberg, A. E., Braunias, S., Hammersberg, P., \& Andersson, C. (2016) Changing from Watermelon Measures to Real Decision Support: Including Information about Variation in Performance Measurements. In Proceedings of the 5th Production \& Operations Management World Conference. Havana, Cuba: Chalmers Publications Library. https://core.ac.uk/download/pdf/84870334.pdf

O’Boyle, E., \& Aguinis, H. (2012). The Best and the Rest: Revisiting the Norm of Normality of Individual Performance. Personnel Psychology, 65, 79-119. https://doi.org/10.1111/j.1744-6570.2011.01239.x

Opfer, K., \& Black, S. A. (2019). Assessing Community Reforestation Projects for Biodiversity Improvement and Poverty Alleviation. Forestry Engineering and Research International, 3, 32-37.

Quammen, D. (2012). The Song of the Dodo: Island Biogeography in an Age of Extinctions. Scribner Island Press, New York.

Quinn, R. E., \& Spreitzer, G. M. (1997). The Road to Empowerment: Seven Questions Every Leader Should Consider. Organizational Dynamics, 26, 37-49. https://doi.org/10.1016/S0090-2616(97)90004-8

Park, S. M., \& Kim, M. Y. (2016). Antecedents and Outcomes of Non-Profit Public Service Motivation in Korean NPOs. International Journal of Manpower, 37, 777-803. https://doi.org/10.1108/IJM-12-2014-0242

Patrick, R. (2009). Performance Management, Gaming and Police Practice: A Study of 
Changing Police Behaviour in England and Wales during the Era of New Public Management. Doctoral Dissertation, Birmingham: University of Birmingham.

Porter, L. J., \& Oakland, J. S. (1991). Process Capability Indices-An Overview of Theory and Practice. Quality and Reliability Engineering International, 7, 437-448. https://doi.org/10.1002/qre.4680070602

Potter, J., \& Hepburn, A. (2010). A Kind of Governance: Rules, Time and Psychology, in Organisations. In N. Llewellyn et al. (Eds.), Organisation, Interaction and Practice: Studies of Ethnomethodology and Conversation Analysis (pp. 49-73). Cambridge: Cambridge University Press. https://doi.org/10.1017/CBO9780511676512.004

Raven, B. H. (2008). The Bases of Power and the Power/Interaction Model of Interpersonal Influence. Analyses of Social Issues and Public Policy, 8, 1-22. https://doi.org/10.1111/j.1530-2415.2008.00159.x

Ramchandran, K., Colbert, A. E., Brown, K. G., Denburg, N. L., \& Tranel, D. (2016). Exploring the Neuropsychological Antecedents of Transformational Leadership: The Role of Executive Function. Adaptive Human Behavior and Physiology, 2, 325-343.

Redpath, S. M., Young, J., Evely, A., Adams, W. M., Sutherland, W. J., Whitehouse, A., Amar, A., Lambert, R. A., Linnell, J. D., Watt, A., \& Gutierrez, R. J. (2013). Understanding and Managing Conservation Conflicts. Trends in Ecology \& Evolution, 28, 100-109. https://doi.org/10.1016/j.tree.2012.08.021

Reis, E. (2011). The Lean Startup. New York: Crown Business.

Restubog, S. L. D., Bordia, P., \& Tang, R. L. (2007). Behavioural Outcomes of Psychological Contract Breach in a Non-Western Culture: The Moderating Role of Equity Sensitivity. British Journal of Management, 18, 376-386.

https://doi.org/10.1111/j.1467-8551.2007.00531.x

Revans, R. W. (1971). Developing Effective Managers: A New Approach to Business Education. Westport, CT: Praeger Publishers.

Robinson, S. L., \& Bennett, R. J. (1997). Workplace Deviance: Its Definition, Its Manifestations, and Its Causes. In R. Lewicki, B. Sheppard, \& R. Bies (Eds.), Research on Negotiation in Organizations (pp. 3-27). Greenwich, CT: JAI Press.

Rousseau, D. M., Sitkin, S. B., Burt, R. S., \& Camerer, C. (1998). Not So Different after All: A Cross-Discipline View of Trust. Academy of Management Review, 23, 393-404. https://doi.org/10.5465/amr.1998.926617

Ryan, R. M., \& Deci, E. L. (2000). Self-Determination Theory and the Facilitation of Intrinsic Motivation, Social Development, and Well-Being. American Psychologist, 55, 68. https://doi.org/10.1037/0003-066X.55.1.68

Scheffer, M., Westley, F., \& Brock, W. (2003). Slow Response of Societies to New Problems: Causes and Costs. Ecosystems, 6, 493-502. https://doi.org/10.1007/PL00021504

Schein, E. H. (2009). Helping: How to Offer, Give, and Receive Help: Understanding Effective Dynamics in One-to-One, Group, and Organizational Relationship.

Scholtes, P. (1997). The Leader's Handbook: Making Things Happen, Getting Things Done. New York: McGraw Hill Professional.

Seddon, J. (2005). Freedom from Command and Control. Vanguard Press, Buckingham, UK.

Senge, P. M. (2006). The Fifth Discipline: The Art and Practice of the Learning Organization. Fort Collins, CO: Crown Pub.

Sheldon, K. M., \& King, L. (2001). Why Positive Psychology Is Necessary. American Psychologist, 56, 216. https://doi.org/10.1037/0003-066X.56.3.216

Shewhart, W. A. (1931). Economic Control of Quality of Manufactured Product. Mil- 
waukee, WI: ASQ Quality Press.

Shippmann, J. S., Ash, R. A., Batjtsta, M., Carr, L., Eyde, L. D., Hesketh, B., Kehoe, J., Pearlman, K., Prien, E. P., \& Sanchez, J. I. (2000). The Practice of Competency Modeling. Personnel Psychology, 53, 703-740. https://doi.org/10.1111/j.1744-6570.2000.tb00220.x

Sjölander-Lindqvist, A., Johansson, M., \& Sandström, C. (2015). Individual and Collective Responses to Large Carnivore Management: The Roles of Trust, Representation, Knowledge Spheres, Communication and Leadership. Wildlife Biology, 21, 175-185. https://doi.org/10.2981/wlb.00065

Smith, M. J. (1975). When I Say No, I Feel Guilty: How to Cope-Using the Skills of Systematic Assertive Therapy. New York: Bantam.

Sparrowe, R. T. (2005). Authentic Leadership and the Narrative Self. The Leadership Quarterly, 16, 419-439. https://doi.org/10.1016/j.leaqua.2005.03.004

Stajkovic, A. D., \& Luthans, F. (1998). Self-Efficacy and Work-Related Performance: A Meta-Analysis. Psychological Bulletin, 124, 240. https://doi.org/10.1037/0033-2909.124.2.240

Straka, T. M., Bal, P., Corrigan, C., Di Fonzo, M. M., \& Butt, N. (2018). Conservation Leadership Must Account for Cultural Differences. Journal for Nature Conservation, 43, 111-116. https://doi.org/10.1016/j.jnc.2018.03.003

Sutton, A. E. (2015). Leadership and Management Influences the Outcome of Wildlife Reintroduction Programs: Findings from the Sea Eagle Recovery Project. PeerJ, 3, e1012. https://doi.org/10.7717/peerj.1012

Turvey, S. (2009). Witness to Extinction: How We Failed to Save the Yangtze River Dolphin. Oxford: Oxford University Press.

Van Vugt, M., Hogan, R., \& Kaiser, R. B. (2008). Leadership, Followership, and Evolution: Some Lessons from the Past. American Psychologist, 63, 182. https://doi.org/10.1037/0003-066X.63.3.182

Voegtlin, C., Boehm, S. A., \& Bruch, H. (2015). How to Empower Employees: Using Training to Enhance Work Units' Collective Empowerment. International Journal of Manpower, 36, 354-373. https://doi.org/10.1108/IJM-10-2012-0158

Vroom, V. H., \& Yetton, P. W. (1973). Leadership and Decision-Making (Vol. 110). Pittsburgh, PA: University of Pittsburgh Pre. https://doi.org/10.2307/j.ctt6wrc8r

Waldman, M. (2013). System Failure: The Underlying Causes of US Policy-Making Errors in Afghanistan. International Affairs, 89, 825-843. https://doi.org/10.1111/1468-2346.12047

Waters, R. D. (2009). The Importance of Understanding Donor Preference and Relationship Cultivation Strategies. Journal of Nonprofit \& Public Sector Marketing, 21, 327-346. https://doi.org/10.1080/10495140802662523

Weiss, M., Hoegl, M., \& Gibbert, M. (2011). Making Virtue of Necessity: The Role of Team Climate for Innovation in Resource-Constrained Innovation Projects. Journal of Product Innovation Management, 28, 196-207. https://doi.org/10.1111/j.1540-5885.2011.00870.x

Wildman, J. L., \& Bedwell, W. L. (2013). Practicing What We Preach: Teaching Teams Using Validated Team Science. Small Group Research, 44, 381-394. https://doi.org/10.1177/1046496413486938

Wofford, J. C., Goodwin, V. L., \& Premack, S. (1992). Meta-Analysis of the Antecedents of Personal Goal Level and of the Antecedents and Consequences of Goal Commitment. Journal of Management, 18, 595-615. 


\section{https://doi.org/10.1177/014920639201800309}

Zaccaro, S., \& Banks, D. (2001). Leadership Vision and Organizational Effectiveness. In S. J. Zaccaro, \& R. J. Klimoski (Eds.), The Nature of Organizational Leadership: Understanding the Performance Imperatives Confronting Today's Leaders (pp. 181-218). San Francisco, CA: Jossey-Bass. 